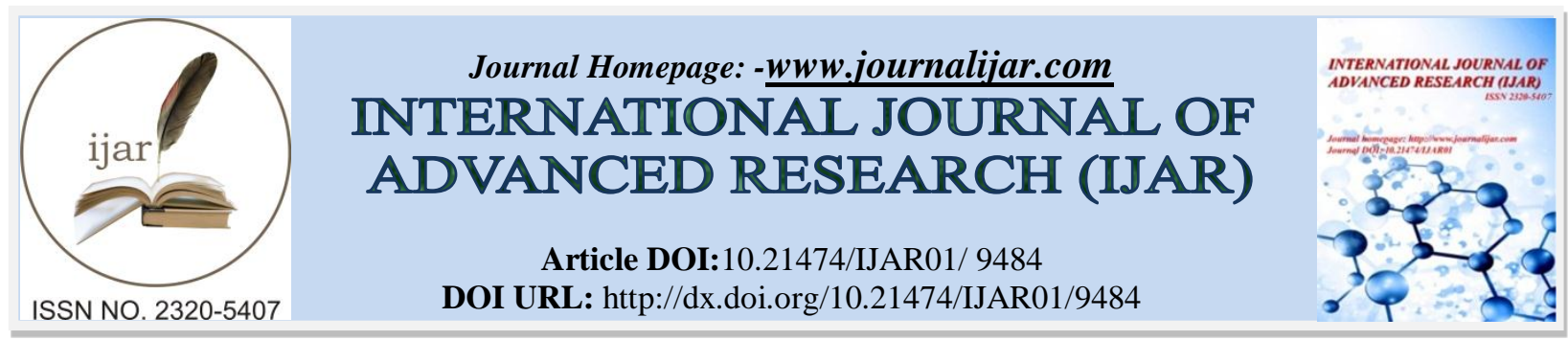

RESEARCH ARTICLE

\title{
COMPARISON OF PRELIMINARY PHYTOCHEMICAL EVALUATION OF KUSHMANDAGIRA SWARASA (JUICE OF SEED CONTAINING PART OF BENINCASA HISPIDA (THUNB.)COGN.) BHAVITHA YASHTIMADHU CHOORNA (GLYCYRRHIZA GLABRA LINN.) AND KEVALA YASHTIMADHU CHOORNA.
}

Niya T Sivan ${ }^{1}$ and Dr Sara Monsy Oommen².

1. PG Scholar, Dept. of Dravyaguna vijnanam, Govt. Ayurveda College, Tripunithura.

2. Professor, Dept. of Dravyaguna vijnanam, Govt. Ayurveda College, Thiruvanthapuram.

\section{Manuscript Info}

.0......................

Manuscript History

Received: 03 June 2019

Final Accepted: 05 July 2019

Published: August 2019

Key words:-

Glycyrrhiza glabra Linn, Kushmandagira swarasa bhavitha Yashtimadhu, Phytochemistry.

\section{Abstract}

Internal administration of Kushmandagira swarasa bhavitha Yashtimadhu choornam is mentioned in the treatment of Apasmara chikitsa of Yogaratnakara where Kushmandagira swarasa is the juice of seed containing part of Benincasa hispida (Thunb.)Cogn. In this study, preliminary physical and phytochemical evaluations of Kushmandagira swarasa (juice of seed containing part of Benincasa hispida (Thunb.)Cogn.) bhavitha Yashtimadhu choorna (Glycyrrhiza glabra Linn.) and kevala Yashtimadhu choorna is done. Phytochemical analysis showed a marked variation in the comparison of extractive values of Kushmandagira swarasa bhavitha Yashtimadhu choorna and kevala Yashtimadhu choorna. Hereby proves the importance of bhavana procedure in the herbal formulations.

Copy Right, IJAR, 2019,. All rights reserved.

\section{Introduction:-}

Yashtimadhu (Glycyrrhiza glabra Linn.) is a well-recognized medicinal plant. The references of Yashtimadhu are available from Vedic period. The drug is described in different contexts in Bruhatrayees. It is the most repeated drug in the 50 Mahakashaya explained by Acharya Charaka. It is stated as chakshushya, balya and vrushya in Bhavaprakasha. Kushmanda (Benincasa hispida (Thunb.)Cogn.) is a vegetable, which is having the immense medicinal property and has an inevitable role in the Indian diet. Kushmanda has been using from the vedic period as a vegetable and as a medicine. Internal administration of Kushmandagira swarasa bhavitha Yashtimadhu choornam is mentioned in the treatment of Apasmara chikitsa of Yogaratnakara. ${ }^{[1]}$ Bhavana is a procedure by which the potency of the herbal formulations can be increased. So in the present study, a comparative phytochemical analysis was done on Kushmandagira swarasa bhavitha Yashtimadhu choorna and kevala Yashtimadhu choorna in order to find the changes happened in the drug, Yashtimadhu after the bhavana with the juice of seed containing part of Kushmanda.

\section{Materials and Methods:-}

Materials of Phytochemical analysis

\section{Preparation of choornam}

Dried roots of Yashtimadhu (Glycyrrhiza glabra Linn.) were powdered and sieved properly using 120 mesh size. Kushmandagira (Seed containing part of Benincasa hispida (Thunb.)Cogn) was crushed and juice was extracted 
using a mixer without adding water. After that suffient amount of Yashtimadhu Choorna(Glycyrrhiza glabra Linn.) was taken and did bhavana with adequate amount of swarasa of Kushmandagira (seed containing part of Benincasa hispida (Thunb.)Cogn.). The trituration was done continuously for three hours and the entire process was repeated for seven times. After the trituration, the powder was again dried, powdered and sieved properly. The prepared drug was preserved in an air tight container.

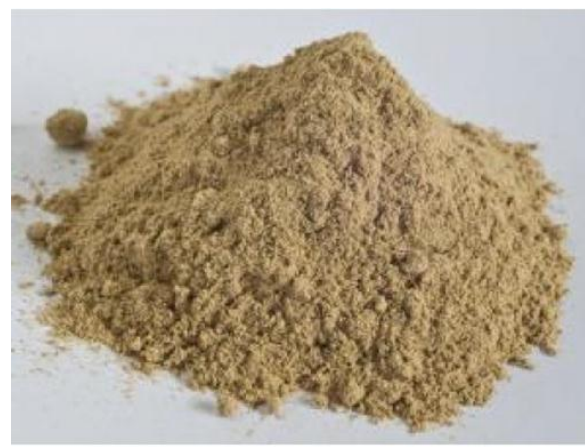

Fig 1:-Yashtimadhu choorna Yashtimadhu

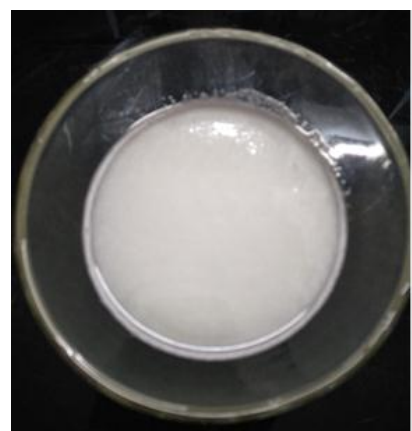

Fig 2:-Kushmandagira swarasa

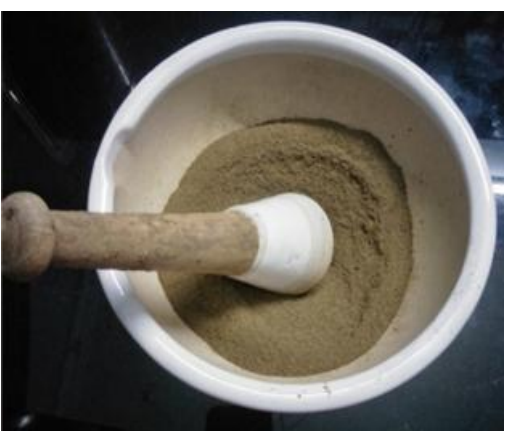

Fig 3:-Kushmandagira swarasa bhavitha

\section{Preliminary Physical and Phytochemical Evaluation}

The physical and preliminary phytochemical analysis was done by standard procedures mentioned in the Ayurvedic Pharmacopoeia of India. Physical evaluation includes Foreign matter, Total ash, Acid insoluble ash, Water insoluble ash, Moisture content, Volatile oil, Fiber content, Tannin content, Total sugar, Reducing sugar, Phenol and pH. Qualitative analysis was done to analyze the presence of steroid, flavonoid, phenol, alkaloid,tannin,carbohydrate,proteins and saponin. Extractive values include water soluble \&alcohol soluble extractives and successive solvent extraction. Qualitative analysis of successive solvent extractives was also done along with qualitative analysis of the ash.

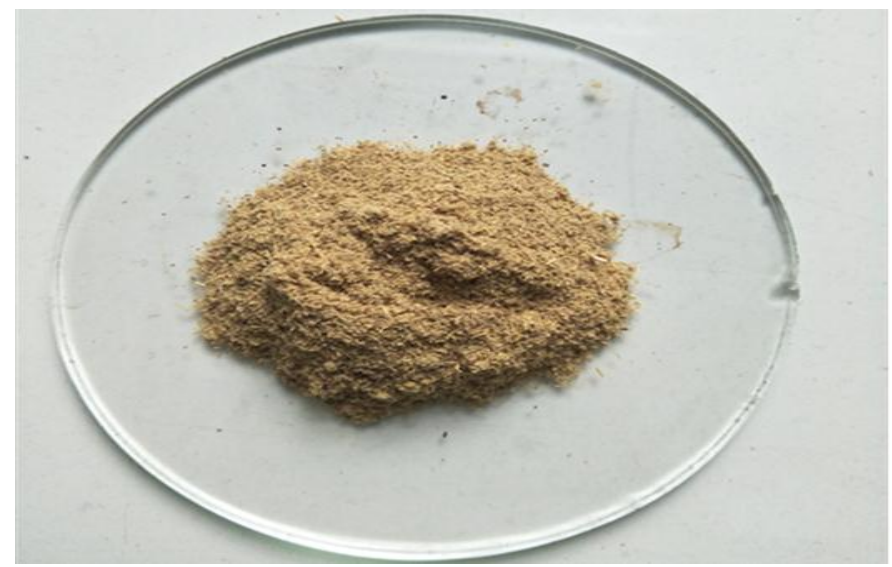

Fig 4:-Kevala Yashtimadhu choorna

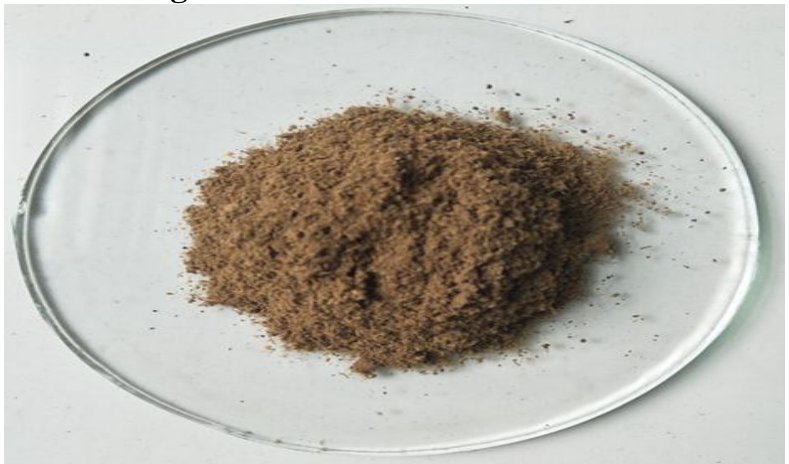

Fig 5:-Kushmandagirotha swarasa bhavitha Yashtimadhu choorna 
Results:-

Results of physico-chemical parameters

Table no 1:-Results of physico-chemical parameters

\begin{tabular}{|r|l|c|c|}
\hline Sl.no & Parameters & $\begin{array}{r}\text { Yashtimadhu } \\
\text { choorna }\end{array}$ & $\begin{array}{r}\text { Kushmandagira swarasa bhavitha } \\
\text { Yashtimadhu choorna }\end{array}$ \\
\hline 1 & Foreign matter & Nil & Nil \\
\hline 2 & Total ash & $5.8 \%$ & $6.4 \%$ \\
\hline 3 & Acid Insoluble Ash & $1.3 \%$ & $2.9 \%$ \\
\hline 4 & Water Insoluble Ash & $1.5 \%$ & $4.9 \%$ \\
\hline 5 & Moisture Content & $5.6 \%$ & $8 \%$ \\
\hline 6 & Volatile oil & Traces & Nil \\
\hline 7 & Fibre & $24.6 \%$ & $28.9 \%$ \\
\hline 8 & Tannin Content & $\mathbf{3 . 1 8 \%}$ & $\mathbf{1 9 . 1 2} \%$ \\
\hline 9 & Total sugar & $5.03 \%$ & $6.78 \%$ \\
\hline 10 & Reducing sugar & $3.4 \%$ & $3.1 \%$ \\
\hline 11 & Phenol & $7.47 \mu \mathrm{g} / \mathrm{g}$ & $8.24 \mu \mathrm{g} / \mathrm{g}$ \\
\hline 12 & $\mathrm{pH}$ & 6.11 & 8.29 \\
\hline
\end{tabular}

Table no 2:-Results of alcohol and water extractive values:

\begin{tabular}{|l|l|c|c|}
\hline Sl no & Type of Extractives & Yashtimadhu choorna & $\begin{array}{c}\text { Kushmandagira swarasa } \\
\text { bhavitha Yashtimadhu choorna }\end{array}$ \\
\hline 1 & Cold Alcohol soluble & $\mathbf{3 . 1 4 \%}$ & $\mathbf{4 4 . 8 8 \%}$ \\
\hline 2 & Hot Alcohol soluble & $46.8 \%$ & $43.91 \%$ \\
\hline 3 & Cold water soluble & $\mathbf{3 . 3 4 \%}$ & $\mathbf{1 3 . 1 6 \%}$ \\
\hline 4 & Hot water soluble & $\mathbf{1 9 . 6 \%}$ & $\mathbf{6 5 . 2 \%}$ \\
\hline
\end{tabular}

Table no 3:-Results of successive solvent extraction

\begin{tabular}{|c|l|c|c|}
\hline SI no & Solvents & $\begin{array}{l}\text { \% of extractive values of } \\
\text { Yashtimadhu }\end{array}$ & $\begin{array}{l}\text { \% of extractive values of } \\
\text { Kushmandagirotha } \\
\text { swarasa } \\
\text { bhavitha Yashtimadhu choorna }\end{array}$ \\
\hline 1 & Petroleum ether & $1.2 \%$ & $0.55 \%$ \\
\hline 2 & Cyclohexane & $0.72 \%$ & $2.65 \%$ \\
\hline 3 & Acetone & $4.07 \%$ & $5.39 \%$ \\
\hline 4 & Alcohol & $2.59 \%$ & $3.04 \%$ \\
\hline
\end{tabular}

Table no 4:-Results of qualitative analysis of crude drugs

\begin{tabular}{|lr|c|c|}
\hline \multicolumn{2}{|c|}{ Test } & Yashtimadhu choorna & $\begin{array}{c}\text { Kushmandagirotha } \\
\text { bhavitha Yashtimadhu choorna }\end{array}$ \\
\hline $\begin{array}{l}\text { Alkaloids } \\
\text { Dragendroff's test }\end{array}$ & ii. Meyer's test & + & + \\
& Flavonoids & + & + \\
\hline & Saponins & + & + \\
\hline Carbohydrates & & + & + \\
i. Fehling's test & ii. Benedict's test & + & + \\
\hline & Proteins & + & + \\
\hline Phenols & & + & + \\
i. Ferric chloride test & ii. Lead acetate test & + & + \\
& & & + \\
\hline
\end{tabular}




\begin{tabular}{|c|c|c|}
\hline Steroids & + & + \\
\hline $\begin{array}{l}\text { Tannins } \\
\text { i. Ferric chloride test }\end{array}$ & $\begin{array}{l}+ \\
+\end{array}$ & $\begin{array}{l}+ \\
+\end{array}$ \\
\hline
\end{tabular}

Table no 5:-Qualitative analysis of successive solvent extractives of Yashtimadhu

\begin{tabular}{|r|l|c|c|c|c|}
\hline Sl no: & Extract & Steroids & Alkaloids & Flavonoids & Phenols \\
\hline 1. & Petroleum ether & + & - & & - \\
\hline 2. & Cyclohexane & + & - & - & - \\
\hline 3. & Acetone & +++ & +++ & +++ & ++ \\
\hline 4. & Alcohol & ++ & + & + & + \\
\hline
\end{tabular}

Table no 6:-Qualitative analysis of successive solvent extractives of Kushmandagira swarasa bhavitha Yashtimadhu choorna

\begin{tabular}{|r|l|c|c|c|c|}
\hline Sl no: & Extract & Steroids & Alkaloids & Flavonoids & Phenols \\
\hline 1. & Petroleum ether & + & - & - & + \\
\hline 2. & Cyclohexane & + & - & - & + \\
\hline 3. & Acetone & ++ & +++ & ++ & +++ \\
\hline 4. & Alcohol & - & + & + & + \\
\hline
\end{tabular}

Table no 7:-Qualitative analysis of ash of test drugs

\begin{tabular}{|c|c|c|c|}
\hline Sl No & Experiment & Yashtimadhu & $\begin{array}{c}\text { Kushmandagirotha swarasa } \\
\text { bhavitha Yashtimadhu }\end{array}$ \\
\hline \multicolumn{4}{|c|}{ Acid radicals } \\
\hline 1 & Carbonate & + & + \\
\hline 2 & Phosphate & ++ & + \\
\hline 3 & Chloride & - & + \\
\hline 4 & Sulphate & - & - \\
\hline \multicolumn{4}{|c|}{ Basic radicals } \\
\hline 5 & Potassium & - & - \\
\hline
\end{tabular}

\section{Discussion:-}

Yashtimadhu choorna was triturated using the swarasa of seed containing part of Kushmanda. The swarasa was taken up to the complete soaking of choorna in the khalwa yantra. Continuous trituration for three hours was done and repeated the bhavana for seven days. After the bhavana, the combination was dried, powdered again and kept in an air tight container. Particle size was reduced considerably after each bhavana. The powder became finer and it possesses rekhapoornatva (filled in the furrows of fingers) and vaaritaratva (floated when sprinkled above the water) property compared to the kevala Yashtimadhu choorna.

Foreign matters were nil in the samples which indicates the absence of physical impurities. The total ash in the both samples was within in the API parameters. It indicates the absence of inorganic impurities. Commercially, inorganic matters were added for the purpose of adulteration. Here, no act of adulteration was performed and the samples were genuine. Acid insoluble ash indicates the presence of calcium oxalate crystals or the silica particles. Here, the Yashtimadhu and Kushmanda contains calcium oxalate crystals. So the combination is having a high acid insoluble ash value than kevala Yashtimadhu choorna. Water insoluble ash is also higher in Kushmandagirotha swarasa bhavitha Yashtimadhu choorna.

Moisture is one of the major factors responsible for the deterioration of drugs and formulations. Low moisture content is always desirable for higher stability of drugs. The moisture content of bhavitha Yashtimadhu choorna was found to be 8, which was under the permissible limit of API parameter of Yashtimadhu choorna. Traces of volatile oil was present in kevala Yashtimadhu choorna and it was absent in bhavitha Yashtimadhu choorna. This may be due the continuous trituration and drying process lead to the loss of volatile contents. Tannin, phenolic and fibre contents of bhavitha Yashtimadhu choorna were higher than kevala Yashtimadhu choorna. Cold alcohol soluble, hot 
water soluble and cold water soluble extractives were higher in bhavitha Yashtimadhu choorna. Hot alcohol soluble extractive was less in bhavitha Yashtimadhu choorna than kevala Yashtimadhu choorna. During the successive solvent extraction, maximum percentage of extracts was found in acetone for both the samples. Least was found in cyclohexane for kevala Yashtimadhu choorna and petroleum ether for bhavitha Yashtimadhu choorna. Percentage of extracts was higher in bhavitha Yashtimadhu choorna than kevala Yashtimadhu choorna except for petroleum ether. In the qualitative analysis of phytochemicals, all the tested phytochemicals such as tannin, protein, saponin etc were present in both the samples. Presence of acid radicals such as carbonate and phosphate were present in the qualitative analysis of ash of both samples.

\section{Conclusion:-}

Both the drugs, Yashtimadhu and Kushmanda are mentioned as Medhya dravyas. Yashtimadhu has mentioned as the Medhya rasayanam by Acharya Charaka, along with the administration of Ksheera. Kushmanda also proved to have the potency to increase the cognitive power in human through various researches. For giving a validation to its therapeutic properties and to standardize the formulation, the preliminary phytochemical analysis had been carried out. From the comparative phytochemical evaluation of Kushmandagira swarasa bhavitha Yashtimadhu choorna and Kevala Yashtimadhu choorna, the quantitative increase of its active phytoconstituents was clearly seen. This certainly increases the potency of the formulation by bhavana.

\section{Acknowledgement:-}

I express my immense respect and gratitude towards Dr.Sara Monsy Oommen, my guide and the Professor of the department of Dravyaguna vijnana, Govt. Ayurveda College, Thiruvanthapuram, for her immense guidance and motivation throughout the work.

\section{References:-}

1. Vaidya Srilakshmipathishastri, Edited by Bhisarantna Brahmasankar Shastri Yogaratnakara with Vidyothini Hindi Commentary, Chaukhambha prakashan, Varanasi. P.no : 500. 